Check for updates

UCL Bartlett Development Planning Unit, London School of Hygiene and Tropical Medicine, London, UK

2 Department of Health Services Research and Policy, London School of Hygiene and Tropical Medicine, London, UK

3 Institute of Global Health, UCL, London, UK

4 Bromley-by-Bow Health Centre, London, UK

Correspondence to: C Stephens Carolyn.Stephens@lshtm.ac.uk Cite this as: BMJ 2021;375:n2828 http://dx.doi.org/10.1136/bmj.n2828 Published: 25 November 2021

\title{
Elder abuse in the UK: out of the shadows and on to the agenda
}

\author{
Primary care has a key role \\ Carolyn Stephens, ${ }^{1}$ Nicolas Mays, ${ }^{2}$ Rita Issa, ${ }^{3}$ Lesley Perkins, ${ }^{4}$ Rebecca Scott ${ }^{4}$
}

Elder abuse is a major public health problem, facing one in six older people globally (defined as aged 60 and older). ${ }^{12}$ Older people with dementia are at much higher risk, ${ }^{3}$ and the disease is predicted to affect over a million people in the UK by $2025 .^{4}$

In 2021, a report by the House of Lords described abuse of older people, particularly those with dementia, as complex, poorly measured, and hidden. ${ }^{5}$ Physical abuse includes violence, but psychological and financial abuse is recorded as the most common form of harm, including manipulation of older people to obtain assets through marriage, wills, and abuse of lasting powers of attorney. ${ }^{6}$ Controlling and coercive behaviour by perpetrators and social isolation of victims make elder abuse difficult to detect or tackle. ${ }^{7}$ The UK General Medical Council recommends that health professionals should be familiar with different types of abuse in order to identify patients at risk, noting that many abuses are now criminal offences. ${ }^{8}$

\section{UK policy changes-and challenges}

Since the previous editorial on this subject in The $B M J$ in 2011, ${ }^{9}$ UK legislation has substantially changed. New domestic abuse crimes have been introduced, including forced marriage $(2014)^{10}$ and coercive and controlling behaviour (2015). ${ }^{11}$ The Domestic Abuse Act 2021 introduced a statutory definition of domestic abuse in UK law for the first time. $^{12}$ The Forced Marriage Unit was established in 2005 to protect victims coerced into marriage, and the Office of the Public Guardian was established in 2007 to protect people from abuse of powers of attorney. In health and social care, adult safeguarding guidance and multiagency safeguarding teams now exist. ${ }^{8}$ Together, these have great potential to prevent abuse or intervene when it occurs.

We do not yet know whether these changes have led to more action against abuse. This is because basic data on the scale of elder abuse in the UK are lacking, creating "systematic invisibility." "For example, the Crime Survey for England and Wales excluded respondents older than 59 until 2017 (it still excludes people older than 74) and does not survey group residences, thereby excluding elderly people in care homes. $^{14}$

Little evidence also exists to quantify action taken by responsible authorities. In the year to March 2020 alone, the police recorded 758941 domestic abuse related crimes in England and Wales, including 24 856 offences of coercive control. The proportion of domestic abuse cases declined by age for women and increased for men, but the data are not disaggregated further. ${ }^{15}$ Most domestic abuse cases are closed by police with no further action. ${ }^{16}$
The Forced Marriage Unit recorded 11519 reports of forced marriages between 2012 and 2020 . We calculate that $9 \%$ (1048 cases) involved people with learning difficulties or mental incapacity, and $20 \%$ of victims were male. ${ }^{17}$ Reports of forced marriages of older people have increased over the past five years. ${ }^{17}$ To date, only four prosecutions have been brought for forced marriage, none involving older people or those with limited mental capacity. ${ }^{18}$

Between 2015 and 2021 the Office of the Public Guardian investigated around 12000 cases of potential abuse of power of attorney. ${ }^{19}$ Again, the majority ended in no action. In 2017 Denzil Lush, a now retired senior judge at the Court of Protection, wrote that he would never sign a lasting power of attorney because "I have seen so much of the pathology associated with powers of attorney and the causes and effects when things go pear-shaped, that I find it difficult to recall cases where powers have operated smoothly." ${ }^{20}$ His coauthor, Caroline Bielanska, commented on the increased digitalisation of the Office of the Public Guardian's processes and increased risks of manipulation of older people. ${ }^{20}$

Two more proposed changes to UK law risk substantially increasing financial abuse of older people: the Law Commission proposes to "modernise" marriage law ${ }^{21}$; and the Ministry of Justice proposes “modernising" lasting powers of attorney. ${ }^{22}$ Both proposals aim to make procedures simpler and easier. Although both include limited safeguards, lawyers and experts argue that these are unlikely to prevent vulnerable individuals, particularly older people with failing capacity, being coerced into either marriage or powers of attorney. ${ }^{2324}$

\section{Role of health professionals}

Health professionals have a vital role in protecting vulnerable older people from abuse. General practitioners and practice teams are often the professionals in closest contact with older patients, and may be the only contact for those who are socially isolated. Primary care is therefore an important space for identifying and recording elder abuse. ${ }^{25}$ Health professionals can also support marriage registrars who become concerned about possible coercion in a marriage process and support solicitors concerned about coercion in the context of powers of attorney or wills. ${ }^{26}$ They can also back MPs lobbying for change. Together, these actions support Age UK's call to increase the visibility of elder abuse. ${ }^{13}$

When protecting vulnerable older adults, health professionals must weigh up the ethical imperative to maintain patient-doctor confidentiality against a duty to escalate concerns to third parties-in patients' best interests-if abuse is witnessed or suspected. ${ }^{27} 28$ 
Furthermore, guidance needs to be developed urgently on the new duties for health professionals to cooperate, enshrined in the 2021 Domestic Abuse Act. ${ }^{29}$ Given the increasing risks of elder abuse in the UK and the rapidly changing legislative environment, health professionals, especially in primary care, would welcome more training-and support-on how to detect, record, and report suspected abuse, so the appropriate action can be taken.

Competing interests: We have read and understood BMJ policy on declaration of interests and declare the following: CS has personal experience of some of the issues raised in the editorial. RS is employed by St Helen's Church Bishopgate as safeguarding officer for one day a week.

Provenance and peer review: Commissioned; externally peer reviewed.

We thank the Office for National Statistics Centre for Crime and Justice for statistical support.

1 Yon Y, Mikton CR, Gassoumis ZD, Wilber KH. Elder abuse prevalence in community settings: a systematic review and meta-analysis. Lancet Glob Health 2017;5:e147-56.

doi: 10.1016/S2214-109X(17)30006-2 pmid: 28104184

2 World Health Organization. World failing to address dementia challenge. 2021. https://www.who.int/news/item/02-09-2021-world-failing-to-address-dementia-challenge

3 Dong X, Chen R, Simon MA. Elder abuse and dementia: a review of the research and health policy. Health Aff (Millwood) 2014;33:642-9. doi: 10.1377/hlthaff.2013.1261 pmid: 24711326

4 Alzheimer Research UK. Dementia statistics hub. 2021. https://www.dementiastatistics.org/statistics-about-dementia/prevalence/

5 House of Lords.Domestic abuse of older people. 2021. https://lordslibrary.parliament.uk/domesticabuse-of-older-people/

6 Crown Prosecution Service. Domestic abuse. Legal guidance. 2021. https://www.cps.gov.uk/legalguidance/domestic-abuse\#a44

7 Safe Lives. Safe later lives: older people and domestic abuse. 2016. https://safelives.org.uk/sites/default/files/resources/Safe\%20Later\%20Lives\%20-\%200lder\%20people\%20and\%20domestic\%20abuse.pdf

8 General Medical Council. Adult safeguarding ethical hub. 2021. https://www.gmc-uk.org/ethicalguidance/ethical-hub/adult-safeguarding

9 Mulroy M, O’Neill D. Elder abuse. BM/2011;343:d6027. doi: 10.1136/bmj.d6027 pmid: 21940746

10 UK Government. Anti-social Behaviour, Crime and Policing Act 2014. Part 10: Forced Marriage. 2014. https://www.legislation.gov.uk/ukpga/2014/12/part/10/enacted

11 UK Government. Serious Crime Act 2015 Part 5 Domestic Abuse. Section 76 Controlling or coercive behaviour in an intimate or family relationship. 2015. https://www.legislation.gov.uk/ukpga/2015/9/section/76/enacted

12 UK Government. Domestic Abuse Act 2021. 2021. https://www.legislation.gov.uk/ukpga/2021/17/contents/enacted

13 Age UK. No age limit: the blind spot of older victims and survivors in the domestic abuse bill. 2020. https://www.ageuk.org.uk/globalassets/age-uk/documents/reports-and-publications/age_uk_no_age_limit_sept2020.pdf

14 Office for National Statistics. Domestic abuse victim characteristics, England and Wales: year ending March 2020. 2021. https://www.ons.gov.uk/peoplepopulationandcommunity/crimeandjustice/articles/domesticabusevictimcharacteristicsenglandandwales/yearendingmarch2020\#datasources-and-quality

15 Office for National Statistics. Domestic abuse and the criminal justice system, England and Wales: November 2020. Responses to and outcomes of domestic abuse cases in the criminal justice system. 2021. https://www.ons.gov.uk/peoplepopulationandcommunity/crimeandjustice/articles/domesticabuseandthecriminaljusticesystemenglandandwales/november2020

16 Her Majesty's Inspectorate of Constabulary and Fire and Rescue Services. The police response to domestic abuse. An update report. 2019. https://www.justiceinspectorates.gov.uk/hmicfrs/wpcontent/uploads/the-police-response-to-domestic-abuse-an-update-report.pdf

17 Forced Marriage Unit. Statistics 2020. 2021. https://www.gov.uk/government/statistics/forcedmarriage-unit-statistics-2020/forced-marriage-unit-statistics-2020

18 Forced marriage-why is the conviction rate so poor? Safeguarding hub blog. Vulnerable adults, 2018. https://safeguardinghub.co.uk/forced-marriage-why-is-the-conviction-rate-so-poor/

19 Office of the Public Guardian. Office of the Public Guardian annual reports 2015-2020. https://www.gov.uk/government/collections/opg-annual-reports

20 Lush D. Lasting and enduring powers of attorney. 8th ed. 2017.https://www.lexisnexis.co.uk/store/_data/assets/pdf_file/0005/492296/Cretney-Lush-Foreword.pdf

21 Law Commission. Property, family and trust law. Weddings. 2021 https://www.lawcom.gov.uk/project/weddings/

22 Ministry of Justice. Modernising lasting powers of attorney. Safe, simpler and fit for the future. 2021. https://consult.justice.gov.uk/opg/modernising-lasting-powers-of-attorney/

23 Sandberg R. Marital problems: The Law Commission's 'getting married' consultation paper and non-qualifying wedding ceremonies. Eccles Law J 2021;23:140-59doi: 10.1017/S0956618X2100003X.

24 Law Society. Modernising lasting powers of attorney-Law Society response. 2021 https://www.lawsociety.org.uk/campaigns/consultation-responses/modernising-lasting-powersof-attorney-law-society-response
25 General Medical Council. Guidance on professional standards and ethics for doctors Decision making and consent. London, GMC, 2020. https://www.gmc-uk.org/-/media/documents/gmcguidance-for-doctors-decision-making-and-consent-english_pdf-84191055.pdf

26 Gilg J-Y. Preventing elderly financial abuse. Family Law2017 https://www.familylaw.co.uk/news_and_comment/preventing-elderly-financial-abuse\#.WjeX69LyjRY

27 General Medical Council. Disclosures for the protection of patients and others. 2021. https://www.gmc-uk.org/ethical-guidance/ethical-guidance-for-doctors/confidentiality/disclosuresfor-the-protection-of-patients-and-others

28 O’Brien JG, Riain AN, Collins C, Long V, O’Neill D. Elder abuse and neglect: a survey of Irish general practitioners. J Elder Abuse Neg/ 2014;26:291-9. doi: 10.1080/08946566.2013.827955 pmid: 24779541

29 Domestic Abuse Act 2021. Duty to co-operate with Commissioner. https://www.legislation.gov.uk/ukpga/2021/17/section/15/enacted 